\title{
Technical budgets are not elastic
}

The British government's ambition to reduce the budget of the European Space Agency by a quarter in the next five years is misconceived, commendable though the search for economy may be.

THE British are notoriously and waywardly in two minds about the European enterprise of "ever closer union", but even British enthusiasts seem to have marked out for themselves a role as Europe's bookkeepers. Last year, Britain's Office of Science and Technology (OST) made a fuss about the proposed cost of building the Large Hadron Collider at CERN at Geneva, and won for all member governments membership subscriptions lower than they would otherwise have been. Now OST is on the warpath again, this time seeking a reduction of subscriptions to the European Space Agency (see page 441). The incentive is domestic; its own budget is under pressure. Success could bring rewards to all, and without them being labelled as trouble-makers as the British seem destined, yet again, to be. But the latest campaign could also cause more trouble than it is worth.

The British goal is arithmetically simple; a reduction in real terms of 25 per cent in membership subscriptions within five years. It is easily understandable that the government should have reached this conclusion; the contribution to ESA is more than two-thirds of everything Britain spends on civil space. Free money is so scarce that British scientists cannot always participate in projects they have helped to design. Yet OST seems not to want to cut into ESA's programme, or at least those parts of it to which Britain has declined to contribute. (ESA operates on parallel twin budgets, with an "à la carte" element from which members may opt out.) The weakness in its case is that there is no objective evidence that ESA's operations are 25 per cent more expensive than they need to be. Such evidence as there is allows room for economy, but by a smaller margin.

Even if OST's position is simply tactical, a prelude to a compromise at a later stage, it is unwise. It is not merely that Britain has won itself a rotten reputation for making trouble on European stages, so that protesting at yet another budget will reinforce an impression that wins enemies, not friends. There are also genuine difficulties in dealing with technical agencies demanding that they should carry out specific programmes within budgets reduced by arbitrary amounts; the situation is familiar to applicants for research grants who are told that their applications have succeeded, but that only 75 per cent of the funds can be granted. Often there is no such thing as 75 per cent of a laboratory assistant, or of an electron microscope. Much the same may be true of ESA; a small cut might be an economy, a larger one could damage the programme seriously.

Discovering empirically how much of ESA's budget can be safely cut is both dangerous and irrational. If Britain indeed has ambitions to be Europe's general-purpose auditor, it should follow those who analyse expenditure carefully, compare the data uncovered with those arising from other sources and should then isolate, for the benefit of ESA's managers and its member-states, where economies might constructively be made. In ESA's case, it is likely that in-house salaries may be greater than those paid to the agency's commercial contractors, which is a case for a policy decision by the agency's council on employment policy. Moreover, audit investigations of this kind need to be conducted on a continuing basis, especially in international organizations where the costs of compromise decisions cannot easily be foretold for decades ahead. But Britain's OST is demanding a once-and-for-all deal whose long-term consequences may themselves be financial extravagances.

\section{Catastrophe on Sakhalin}

Russia still expects too much stoicism of its large population and must learn to look after its people better.

THE dreadful loss of life in last week's earthquake on Sakhalin Island says three things about the condition of modern Russia. First, the dwellings constructed in Soviet times to house those tempted to work in this distant oil field were replicas of the apartment blocks run up in recent decades in and about most Russian cities. Jerry-built, they were inappropriate to their wilderness environment and virtual death-traps in a seismic region such as this. When Russia can generate the resources necessary, it will have to replace much of the housing-stock in which people now live.

Second, vast Russia is poorly equipped to counter the effects of natural disasters. And that is not simply because resources are scarce; the problem is also psychological, born of the deep-rooted conviction that natural and other catastrophes will eventually be got rid of by research and its application, and that rescue is an inelegant stop-gap solution. The third lesson of Sakhalin is linked with the second; a high degree of fatalism is expected of the Russian people, now as it was in Soviet times (see also page 437). In Moscow, which is eight time-zones away, prominent politicians are occupying themselves again with the dignities that go with being a great power. Should they not pay equal attention to the comfort and safety of their people? 